\title{
Kelly J. Stage. Producing Early Modern London: A Comedy of Urban Space, 1598-1616. Lincoln: University of Nebraska Press, 2018. Pp x, 342. Hard- back USD \$55.00. ISBN: 9781496201812.
}

\section{MATTEO PANGALLO \\ Virginia Commonwealth University}

The city comedy genre of Renaissance drama has experienced something of a renaissance of its own of late. Following initial investigations by Brian Gibbons (1968), Alexander Leggatt (1973), Gail Kern Paster (1985), and Theodore Leinwand (1986), the past two decades have seen many new explorations from scholars such as Janette Dillon (2000), the contributors to Plotting Early Modern London (2004), Jean Howard (2007), Darryll Grantley (2008), Julie Sanders (2011), Adam Zucker (2011), the contributors to Performing Environments (2014), and Nina Levine (2016). To merit mapping out another foray into this territory, as Kelly Stage seeks to do, thus requires that a scholar has a substantial, new claim to stake out. Producing Early Modern London proposes to show how city comedies 'produce and modify the idea of London through the theatrical negotiation of comedy, space, and place' (29). To do this, the book aims to demonstrate how theatre constructed Londoners' conceptualizations of - using Yi-Fu Tuan's terminology — their city's 'places' (physical locations) and 'spaces' (points constructed by social activities). ${ }^{1}$ Rather than seeing these plays as merely reflecting life in London's places, Stage sees the genre as participating in the building of urban spaces. Making a claim about the 'productive' work of literary works is familiar new historicist territory, and, in the process of pursuing it, Producing Early Modern London offers useful original readings of several city comedies; however, because of that familiarity, they do not entirely add up to a particularly revelatory or specific argument, so much as a broad restatement of conventional critical truisms about the genre.

The first chapter explores how Haughton's Englishmen for My Money and Jonson's Every Man Out of His Humour create for the audience a sense of estrangement from previously familiar urban spaces. Stage's reading of Englishmen is persuasive, especially her observation of how Frisco's misleading trip through the city for the foreign suitors produces its dislocated sense of London by means of the empty stage platform on which it is performed. The actors' performances within the open architecture of the playing 'space' compel the audience to consider how performances in the urban 'space' that it represents can make one an alien even in one's own 'place'. In Every Man Out, Stage focuses on how the use of the aisle 
of St Paul's as a space of 'artifice' (that is, self-performance) and the un-spaced chorus scenes both draw audience members' attention to their own 'performative function' in the city by distinguishing those who possess 'urban knowledge from those who do not' (74). It is unfortunate little historical evidence survives about the effects these plays actually produced for early modern audience members' perceptions of their urban environment; like most literary criticism of early modern drama, Stage's must rely on the assumption that the critic's interpretive response accurately, and intuitively, reflects that of the early modern audience, whose interpretive authority then, in a circular fashion, the critic deploys to justify their own claims.

Chapter two focuses on Westward Ho, Northward Ho, and Eastward Ho, three plays that draw upon the relationship between London and its extra-mural communities. Through intersections between the plays and contemporary works, such as Dekker and Middleton's Meeting of Gallants at an Ordinary and Dekker's The Wonderful Year — as well as later works, such as Camden's 1610 Britain and Peacham's 1642 The Art of Living in London - Stage explores the creation of the idea of the city's periphery, as well as the nature of productive mobility between the urban centre and that periphery. This leads into the book's most effective close reading, considering how Westward Ho encodes anxieties about urban disease, and especially the 1604 plague outbreak, within city comedy conventions of sexuality and social disorder. The readings of the other two plays are not quite as compelling. Stage's conclusion, for example, that Northward Ho 'looks beyond London to realize a network of relationships that establish the city's commercial and cultural connections to the periphery in ways that move beyond simple assumptions of city and country codings' is surely correct, though it seems rather too self-evident in the play to necessitate an extended close reading (113).

Using de Certeau's concept of 'tactics', or acts of resistance, chapter three considers how characters in Middleton and Dekker's The Roaring Girl and Jonson's Epicene assert freedom from and within urban spaces. ${ }^{2}$ Stage presents a compelling case for how Moll Frith's status as an 'exemplary tactician' allows her to resist the social norms of those spaces (141). That case, however, succumbs to a false choice fallacy to defend the novelty of the interpretation: Stage notes that earlier critics have seen Moll's 'urban circulation [as] the result of her rebellious femininity', and then contends that reading Moll through de Certeau's idea of tactics 'change[s] the terms of the debate' (143). This does not, however, so much 'change' the terms as reiterate them: claiming that Moll does not represent 'a recuperated female subject or a mouthpiece for radicalism' but, instead, someone who 'takes advantage of the situations in which she finds herself' overlooks 
how these interpretations are not exclusive but, rather, mutually reinforcing (162). Turning to Epicene, Stage focuses on the play's enactment of conflicts between the domestic space of the individual and the urban space of the community, as well as between the spaces of Westminster and the City. In these conflicts, those who have the wit to master urban noise prevail, by being able both to resist and to deploy it. Noise is, in effect, a form of city space that is pervasive and, potentially, intrusive. In a convincing argument, Stage shows that the ways in which mere noise, rather than the best noise, is rewarded in the play serve to critique the extent to which the town and its leisure culture inflected social structures in the urban community.

The final chapter claims, in a somewhat cumbersome turn of phrase, that Middleton's A Chaste Maid in Cheapside 'makes' London in its struggle to 'contain' London while London 'makes' a play that struggles to 'contain' its complex plot (190). Stage approaches the play through the ideas of containment and liquidity, as portrayed in the opposition between the city's static places and dynamic spaces. In doing this, the chapter pairs Chaste Maid with Stow's Survey of London. Stow's efforts to transform London into a shared space are read in tandem with Yellowhammer's vision of the city as a 'citizen's object' (194). Ultimately, however, it is not clear what the close reading of Chaste Maid really gains from the digression on Stow's Survey. Later, the chapter comes around to the familiar reading of the female body, the household, and the city as examples of the 'problems of containment', especially in the middle of the play when 'the dominant spatial idea in the play becomes liquidity' (214-15). This leads into a similarly strained comparison between Allwit's situation and the historical movement and regulation of water around London. Moll's attempted escape from London is also compared to the ways water moved out of the city and then to visual representations of London, such as the Agas map. Once again, the warrants are not clear, nor does the close reading really require these comparisons since its conclusions are already apparent in the play.

The epilogue - effectively a chapter on Jonson's Every Man in His Humour posits that one reason for the demise of city comedy after 1616 was the changing nature of the city itself. With London's practical absorption of many of the suburbs, including Westminster and Holborn, and the migration of much of London's theatrical culture to the West End, Stage concludes that 'city comedy [had] nowhere else to go' (238). The claim is a puzzling one, since such an enlargement of what was inclusive of the 'city' would seem to mean the opposite: city comedies had more territory to explore. Indeed, that is precisely what happened: as Stage herself points out, a new generation of Caroline comedy turned its satirical eye 
upon these new urban spaces and, like all dramatic genres over time, the conventions of 'city comedy' shifted accordingly.

Unfortunately, burdening the book are problems with writing that often impede clear understanding of its claims and analyses, including awkward and vague wording, confused syntax, and unnecessarily reductive statements ('Theaters are definitely special places in London where people go to see plays' [19], 'Plays are far simpler than the actual world' [94], 'Early modern London was not uniform' [253]). Readers willing to work through those problems will benefit from several important close readings of a handful of canonical early modern plays. While the book overall does not transform greatly our critical or historical understanding of the genre, many of these case studies will be important reading for future scholars looking to continue the work of mapping the territory of the city comedy.

\section{Notes}

1 Yi-Fu Tuan, Space and Place: The Perspective of Experience (Minneapolis, 1977).

2 Michel de Certeau, trans. Steven Rendall, The Practice of Everyday Life (Berkeley, 1984). 